\title{
Sentido da colonização e revolução brasileira: crítica de caracterizações do modo de produção colonial
}

\author{
Sense of colonization and Brazilian revolution: \\ criticism of the descriptions of the colonial production mode
}

\author{
Carlos Alberto Cordovano Vieira \\ Professor doutor do Instituto de Economia da Universidade Estadual de Campinas (IE-UNICAMP), Brasil. \\ cordovanovieira@yahoo.com.br
}

Resumo: O presente trabalho pretende esboçar uma leitura crítica das visões do passado colonial elaboradas por Nelson Werneck Sodré, Jacob Gorender e Ciro Cardoso, a partir da consideração da centralidade da dimensão mercantil na determinação do "sentido da colonização".

Palavras-chave: Capital mercantil. Escravismo. Colonização. Marxismo
Abstract: This article aims at outlining a critical reading of Nelson Werneck Sodré, Jacob Gorender and Ciro Cardoso's views of the colonial past, from the consideration of the merchant dimension centrality in determining the "sense of colonization."

Keywords: Merchant capital. Slavery. Colonization. Marxism.

\section{Introdução}

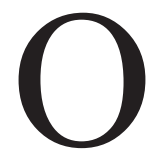

Brasil vive hoje a crise final do "programa democrático-popular". A esperança de que a passagem da ditadura e a consolidação de uma "democracia restrita" pudesse criar espaço para reformas progressivas que caminhassem rumo à superação de nossas mazelas seculares chegou a seu limite com o fim melancólico de mais de uma década de governo do PT. O substrato desse programa era a tese segundo a qual o "capitalismo tardio" brasileiro, não obstante suas evidentes debilidades, já havia chegado a um estágio relativamente avançado da chamada "autodeterminação do capital". A industrialização pesada, vista sob o prisma da internalização do "departamento" produtor de meios de produção, teria significado a superação definitiva das 
heranças da economia colonial e a consolidação de um capitalismo, digamos, plenamente constituído. Daí em diante, os percalços da economia brasileira deixavam de ser problemas estruturais de uma economia de origem colonial para ser oscilações cíclicas próprias de um capitalismo "autodeterminado". Mais que isso, em que pesem as oscilações cíclicas, as bases do capitalismo brasileiro permitiriam a construção de um projeto social-democrata (Cardoso de Mello, 1998; Tavares, 1998). Foi sobre tal base interpretativa que se pôde imaginar que, durante o brevíssimo período recente de modesto crescimento econômico, impulsionado sobretudo pela demanda chinesa, estivéssemos revivendo uma experiência de desenvolvimento a que se chamou "neodesenvolvimentismo".

O país, contudo, se desindustrializava e caminhava para a reprimarização. Na verdade, em 1992, Celso Furtado já observava que a diluição do espaço econômico nacional no curso da transnacionalização do capitalismo contemporâneo viria reafirmar um processo típico de reversão neocolonial (Furtado, 1992).

Esse diagnóstico enseja uma retomada da obra de Caio Prado Jr., em que a tese da "reversão neocolonial", em toda a sua densidade, foi elaborada para explicar as mudanças de longa duração por que passava a formação brasileira na quadra histórica que se definiu com o golpe de 1964 (Prado Jr., 1978). A posição subjacente às discussões desenvolvidas no presente trabalho se pauta no diagnóstico segundo o qual a reversão estrutural por que passa a formação brasileira, que marca a crise do "programa democrático-popular", recoloca, naturalmente para serem rediscutidos à luz das mudanças do capitalismo contemporâneo, os termos da problemática em torno da revolução brasileira, ceifada com a ditadura (Sampaio Jr., 1999). Nessa perspectiva, entendemos pertinente retomar temas fundamentais do debate em torno da revolução brasileira das décadas de 1960 e 1970, para construir uma crítica aos pressupostos do "programa" hoje em crise: a natureza do capitalismo brasileiro e o peso da herança colonial, o estatuto da questão nacional e o imperialismo, o caráter da burguesia brasileira etc.

Os objetivos do presente trabalho, contudo, são bem mais modestos. Procuramos recuperar criticamente, em duas vertentes particulares da historiografia referida ao materialismo histórico, visões de conjunto de nosso passado colonial que estavam na base de diferentes diagnósticos quanto aos dilemas do 
Brasil contemporâneo e, pois, conduziam a diferentes posições quanto ao programa da revolução brasileira. Trataremos especificamente da obra de Nelson Werneck Sodré, mais identificada à ortodoxia do Partido Comunista, e da obra de Jacob Gorender - enriquecida com as contribuições de Ciro Cardoso produzida na década de 1970, no quadro da crise da ortodoxia. Nossa crítica será orientada principalmente pela obra de Caio Prado Jr. Em Caio Prado Jr. (1971), a dimensão mercantil como determinante do sentido da colonização estava na raiz mais funda da teoria da revolução brasileira. Assim, era momento fundamental do debate a caracterização da sociedade colonial ou, digamos, do "modo de produção" vigente na colônia. Nessa perspectiva, procuraremos problematizar as tentativas de identificar na colônia a vigência de modos de produção relativamente autônomos face às determinações mercantis do sistema colonial.

\section{Escravismo e feudalismo}

O problema fundamental que orienta o conjunto da vasta obra historiográfica de Sodré é o da revolução brasileira. As questões concernentes a esse debate, que toma corpo sobretudo na década de 1960 e que dizem respeito ao sentido mais geral das transformações em curso naquela mesma quadra histórica ou, mais propriamente, ao caráter da revolução brasileira em curso, bem como ao arco de alianças colocado aos comunistas brasileiros, são as preocupações centrais subjacentes às indagações feitas ao passado colonial.

Em vista de toda sua densidade, parece uma simplificação exagerada tomar a obra de Sodré como mera reprodução mecânica das teses da ortodoxia soviética, como muitas vezes se fez. No entanto, é correto dizer que sua perspectiva em torno do caráter democrático-burguês, antifeudal e anti-imperialista - e, nesse sentido, nacional - da revolução brasileira, e o corolário da política de alianças com a chamada burguesia nacional confluíram na mesma direção da política, digamos, "oficial” dos comunistas brasileiros.

Para Sodré, a revolução brasileira consistia numa espécie de acúmulo gradual e progressivo de transformações que caminhavam no sentido da 
consolidação do modo de produção capitalista em bases nacionais por meio de choques permanentes contra forças residuais de conservação referidas a formas pré-capitalistas de produção herdadas do passado colonial - notadamente o latifúndio considerado "feudal" (ou "semifeudal"), em vínculos orgânicos com o imperialismo. O latifúndio preservava relações de produção, tomadas como resquícios de formas servis, que operavam como entraves à generalização de relações de formas especificamente capitalistas e, sobre essa base, ao pleno desenvolvimento das forças produtivas nacionais. Com efeito, o latifúndio, conformado pelo predomínio do capital estrangeiro sobre as linhas de financiamento e comercialização, era causa de profunda instabilidade para o capitalismo nacional em virtude das tendências à superprodução no mercado mundial e de seus efeitos deletérios sobre o estreitamento do mercado interno. De outro lado, o capital estrangeiro, que, numa primeira etapa, vinculava-se ao modelo primário-exportador, no momento seguinte avançava sobre o processo de industrialização pesada, impondo, necessariamente, um processo de acumulação dirigido para o exterior, agravando os desequilíbrios externos e as tendências ao endividamento.

Com isso fica evidente a centralidade do problema da caracterização do modo de produção herdado do passado colonial nos marcos do debate em torno da revolução brasileira.

O tema, contudo, não é trivial. Ao lado das mais severas críticas contra a tese da existência de um "feudalismo" no Brasil ou na América Latina, a noção de "feudalismo", como chave explicativa, está presente em diversos momentos do pensamento brasileiro, em várias vertentes. O problema se torna mais difícil porquanto a própria definição de "feudalismo" na historiografia é difusa. Ora identificado à fragmentação política, ora à economia natural, ora às relações de servidão ou mesmo às instituições medievais, o conceito é, desde logo, movediço. Na obra clássica de Oliveira Vianna (1987) encontra-se o exemplo de uma caracterização do campo brasileiro à luz de uma noção de "feudalismo" referida à fragmentação política, à precariedade das bases do Estado em face do poder de potentados locais, como vetores de forças centrífugas que obstam a formação nacional. Noutro polo do espectro político, Celso Furtado, por exemplo, designando "feudalismo" nos termos de uma economia natural, chega a 
fazer menções esparsas a essa caracterização, sobretudo a propósito da formação do complexo nordestino (Furtado, 1995). Alberto Passos define o feudalismo brasileiro em termos das instituições medievais transplantadas de Portugal: "No sistema de plantação, como aliás no conjunto da economia pré-capitalista do Brasil colônia, o elemento fundamental, a característica dominante à qual estavam subordinadas todas as demais relações econômica, é a propriedade agrária feudal" (Guimarães, 1981, p. 30).

Não por outra razão, o tema é controverso mesmo nos limites do materialismo histórico. Ora, é bastante conhecida a tendência, sob a égide da ortodoxia soviética, à omissão do chamado "modo de produção asiático", à delimitação do "modo de produção antigo", referido essencialmente à forma escravista, e ao alargamento, talvez desmedido, do conceito de "feudalismo" (Hobsbawm, 1977). Notemos, a propósito, que o debate clássico da transição do feudalismo para o capitalismo, a partir da obra de Maurice Dobb, revela, por exemplo, nas diversas posições em jogo, uma espécie de entendimento comum de que o feudalismo não era um fenômeno restrito à cristandade europeia medieval por mais de uma vez surge o termo "feudalismos", no plural.

Isso corresponde a duas ordens de problemas. Primeiro, se a mobilização de $A$ origem da familia... pela ortodoxia conduziu à reivindicação de um nexo unívoco entre divisão do trabalho e formas de produção, o excerto Formações econômicas pré-capitalistas revelava que as formas comunistas primordiais deram origem, conforme o caso, a formas de produção bastante diversas, reunidas sinteticamente sob as definições das formas asiática, antiga e germânica. Em segundo lugar, cumpre observar uma vez mais que o alargamento do conceito de "feudalismo", enquadrado no encadeamento sucessivo de um conjunto limitado de modos de produção predeterminados, trazia, como corolário, a perspectiva política da revolução democrático-burguesa nos países de origem colonial - corolário bem adequado à política soviética para os comunistas da "periferia", uma vez consolidada a tese do socialismo num só país.

Mas a tendência ao alargamento do conceito de "feudalismo" ligava-se a outra, bastante comum no mesmo contexto: a tendência a praticamente identificar "modo de produção" com "relações de produção". Nesse caso, excluídas a escravidão, condição bastante inequívoca, e o salariato moderno, todas as 
outras formas surgem como espécies de servidão que, nesse caso, se identificam com diversas formas de feudalismo - no limite, as complexidades das formas concretas tendiam a ser contornadas por meio de artifícios semânticos como "semisservidão" ou "semifeudal". Essa tendência é clara, por exemplo, na tese de Dobb sobre a formação do capitalismo, em que, embora o conceito de modo de produção seja apresentado em termos de articulações de forças produtivas, relações de produção, formas de propriedade etc., o problema da transição é enfim reduzido à transição da servidão ao salariato.

Torna-se claro, portanto, em que sentido Sodré toma um conjunto de relações de produção fundadas na coerção extraeconômica, presentes no latifúndio de origem colonial, como expressões empíricas do "feudalismo" ou dos "resquícios feudais" no Brasil.

Isso posto, cumpre examinar, na obra em tela, as tensões entre os parâmetros conceituais estabelecidos e o movimento concreto da formação histórica do Brasil no que respeita, particularmente, ao passado colonial e escravista. Desde logo, a obra de Sodré não permite a identificação, não tão incomum, entre a existência do capital mercantil na época moderna, como capital restrito à órbita da circulação, e o predomínio da forma específica do modo de produção capitalista. Mais que isso, procura sustentar que o desenvolvimento do capital mercantil e, pois, do sistema colonial, como processos característicos do modo de produção feudal, mesmo que em decomposição, não jogam, por si, em favor da transição ao capitalismo. "O processo de que surge o capitalismo é, pois, endógeno; ele surge de condições internas do país ou região em que se implanta; não surge de condições externas, não surge do capital comercial, como causa única e necessária. Surge na esfera de produção" (Sodré, 1976, p. 29). Assim, restrito à órbita da circulação, sem determinar o conteúdo do "modo de produção" vigente, tudo se passa, a princípio, como se o capital mercantil operasse tão somente no espaço da ligação entre dois modos de produção relativamente autônomos; como se ligasse, tal qual elemento exterior à determinação dos "modos de produção" em causa, o feudalismo metropolitano em crise e o escravismo presente na colônia. Do mesmo modo, a centralização monárquica corresponderia à constituição de um Estado essencialmente feudal, não se confundindo com a formação do Estado propriamente moderno, produzido no bojo das revoluções burguesas. 
No entanto, no estudo do movimento histórico da formação, em particular no estudo da história colonial, Sodré revela, mais do que os parâmetros conceituais preliminares pudessem sugerir, a centralidade da empresa mercantil, definida como a verdadeira "finalidade da colonização", para não dizer o sentido. O desígnio da exploração mercantil, a "finalidade da colonização", é o que, ao fim e ao cabo, explica a "regressão" do feudalismo metropolitano, no espaço da colonização na América, a um modo de produção escravista. Quanto a isso, não escapa a Sodré que o excedente produzido pela economia colonial é dirigido para fora, em proveito do capital mercantil, porquanto a acumulação "não se opera na área da produção, mas na área da circulação, o que decorre do fato fundamental de que a produção depende da circulação, na fase do capital comercial", sendo a empresa açucareira, "empresa do capital comercial, montada para servi-lo"; em suma, "é a circulação, assim, que comanda a produção" (Idem, p. 85).

A tensão entre o movimento concreto da sociedade colonial, ou seu potencial de acumulação, condicionado desde a gênese pelos desígnios da empresa mercantil, e a caracterização do modo de produção escravista a partir da forma das relações de produção é enfrentada por uma espécie de justaposição de duas dimensões: uma "universal"; outra "particular", ou propriamente "americana":

Claro está que, visto o problema na dimensão universal, apresenta-se de determinada maneira; visto na dimensão americana, apresenta-se de outra maneira. Assim, na dimensão universal trata-se do processo de acumulação primitiva, quando eram vigentes as formas pré-capitalistas do capital — no caso, o capital comercial. Mas, na dimensão americana — sul-americana, no caso — trata-se de escravismo puro e simples. (Sodré, 1990, p. 12; grifos nossos)

Cumpre, pois, sublinhar o seguinte ponto: no momento de definir a particularidade desse modo de produção escravista "puro e simples", surge, a rigor, a centralidade da empresa mercantil, da condição propriamente colonial. Ora, se a própria gênese do escravismo remete à empresa mercantil, o mesmo se dá na passagem do "escravismo" ao "feudalismo" - novamente, "a circulação comanda a produção". Não sendo o "escravismo" brasileiro produto da diferenciação da comunidade primitiva, também o "feudalismo" não é uma forma 
subsequente correspondente a um estágio mais elevado de desenvolvimento das forças produtivas, mas uma regressão. Decorre daí a caracterização, por Sodré, do fenômeno da "regressão feudal". Com efeito, a chamada "regressão feudal", que diz respeito principalmente à formação do complexo nordestino e à produção para subsistência residual da economia mineira, é determinada pelas crises da exploração colonial, do açúcar ou do ouro.

Desse modo, ao destacar formalmente a dimensão das relações de produção escravistas da totalidade concreta que lhe confere sentido, ao separar conceito e História, a justaposição entre as dimensões universal e particular parece não encontrar seu momento de síntese. O propósito de mobilizar o conceito de modo de produção para captar o sentido histórico da formação dá lugar a uma narrativa em que o próprio movimento da história é condicionado por forças que, a princípio, foram colocadas à margem do próprio conceito. A forma abstrata de conceitualizar o "modo de produção" leva ao embaraço de se considerar sob uma única definição (escravismo ou feudalismo) experiências históricas em tudo mais distintas, a não ser quanto à forma das relações de produção. A differentia specifica que caracteriza o escravismo antigo e o escravismo moderno ou o feudalismo europeu e as formas de trabalho compulsório nas colônias se diluem nas formas gerais da escravidão e da servidão. ${ }^{1}$ Mas as especificidades ressurgem com toda a força tão logo se volte à narrativa histórica. Desta forma, as duas dimensões, "universal" e "americana", permanecem apartadas sem que se possa transitar de uma a outra, assim como o conceito e a História, sem que se explicitem as mediações entre os dois níveis.

O problema revela a necessidade de se tomar as relações de produção nos marcos da totalidade que thes dá o sentido. Nas Formações..., Marx elaborou um exercício retrospectivo para distinguir a especificidade das relações capitalistas face a outras formas de produção. Ao considerar a separação entre

1. Quanto a esse ponto fundamental, é sintomático que a posição de Sodré tenha oscilado. Em resposta a Gorender, Sodré (1987) reafirmou a tese do "escravismo puro e simples", sem qualificações. Mas em Introdução à revolução brasileira, sustenta tratar-se, o escravismo colonial, de um fenômeno histórico específico referido ao capital mercantil, essencialmente distinto do escravismo antigo: "Trata-se, no caso, pois, de uma decorrência particular ao desenvolvimento do capital mercantil, nada tendo a ver, senão a semelhança, com o escravismo de época histórica mais recuada, quando o motivo de sua vigência foi inteiramente diverso" (Sodré, 1978, p. 68; grifos nossos). 
produtores e meios de produção e subsistência, Marx observa que apenas no modo de produção capitalista a extração do excedente opera por meio de mecanismos, digamos, estritamente "econômicos". Somente nessas condições, com a mediação da mercadoria, sob o véu do dinheiro, produtores e proprietários se postam, uns diante dos outros, como encarnações de categorias econômicas. Ao passo que, nas formações pré-capitalistas, à exclusão da comunidade primeva, o excedente é extraído por meio de diversas formas de coerção extraeconômica. Daí porque, nessas formas, esses nexos extraeconômicos, muito mais que epifenômenos exteriores e passivos, determinados pela "economia", constituem, sim, elementos intrínsecos às relações de produção. Desta maneira, a passagem do exercício conceitual e retrospectivo à reconstituição propriamente histórica exigiria a concreção orgânica dessas formas de produção nos marcos da totalidade em causa. Somente aí seria possível apreender seu sentido histórico. A propósito, na famosa "Introdução" às Formações..., Hobsbawm observa que as formas de produção em si mesmas, limitadas em sua variedade, são, no bojo das diversas experiências históricas, criadas e recriadas, encarnando sentidos também diversos, em cada contexto. Mais que um modo de produção escravista (ou feudal) "puro e simples", trata-se, sim, da escravidão moderna, colonial, constitutiva do processo de transição ao capitalismo, cujo sentido histórico encontra-se justamente nessa vinculação essencial com o sistema colonial do capital mercantil e as monarquias em formação.

\section{Escravismo colonial}

A perspectiva do "escravismo colonial" procura, a seu modo, dar conta desses problemas. ${ }^{2}$ Vejamos.

Na obra de Gorender, no contexto da década de 1970, a problemática da formação nacional dá lugar à questão da especificidade do capitalismo brasileiro. Tal especificidade remete em primeiro lugar a sua gênese. Quanto a isso, o ponto central, para Gorender, consiste em observar a existência de duas variantes

\footnotetext{
2. No presente trabalho procuramos tratar a "perspectiva do escravismo colonial" a partir do diálogo entre Gorender e Ciro Cardoso.
} 
no processo de transição ao modo de produção capitalista: a transição que tem, como ponto de partida, o modo de produção feudal e a que tem o modo de produção do escravismo colonial. Noutros termos, o escravismo colonial, tomado como modo de produção, constitui uma das variantes da transição ao capitalismo. O pressuposto residiria numa suposta capacidade de acumulação interna. A tese, portanto, seria construída como crítica à tradição, que procura definir o sentido da colonização à luz da órbita da circulação, das teias mercantis do capitalismo em formação e que, como corolário, chega à extroversão e à externalidade da acumulação como características fundamentais da sociedade colonial. Para Gorender, definir o modo de produção do escravismo colonial é, ao mesmo tempo, postular a possibilidade de acumulação interna que opera como vetor de uma das variantes da transição ao capitalismo. ${ }^{3}$ Nesse sentido, o entrave à plena constituição do capitalismo no Brasil residiria precisamente na preservação, durante o século XIX, das relações de produção escravistas. Daí o porque de o ponto crítico da formação do Brasil contemporâneo recair precisamente na abolição da escravidão.

Removidos os obstáculos das relações escravistas, o modo de produção capitalista viria a desenvolver-se sob uma dupla determinação de forças "externas" e "internas", estas condicionando as primeiras. A entrada do capital estrangeiro nas etapas mais avançadas da industrialização potencializaria o capitalismo brasileiro, com a internalização do departamento produtor de meios de produção, condicionado pelo capital nacional e pelo Estado. Há, portanto, removidas as relações escravistas, um desenvolvimento quase linear do capitalismo brasileiro. Mais que isso, Gorender vê nesse capitalismo já em estágio avançado, em meados da década de 1970, o embrião de um imperialismo brasileiro - embora reconheça a ausência de um capital financeiro engendrado a partir de dentro. Dessa reorientação interpretativa do passado colonial e, pois, do Brasil contemporâneo, decorre uma transfiguração do que era a problemática

3. "Na Europa, a acumulação originária do capital realizou-se no bojo do feudalismo. No Brasil, nunca houve feudalismo, o que Caio Prado Jr. foi o primeiro a notar. A acumulação originária de capital se processou no âmbito do escravismo colonial e tendo este como a fonte da própria acumulação. Mais ainda: a base para a cumulação originária do capital começou a se formar na época em que o Brasil foi colônia de Portugal. Nem toda a renda produzida no Brasil era, então, dirigida para fora, conforme supõe Florestan Fernandes, porém uma parte muito considerável ficava na própria Colônia” (Gorender, 1990, p. 8). 
central da revolução brasileira na década de 1960: esvazia-se o sentido da questão nacional. Ligado a isso, esvai-se qualquer perspectiva em torno de uma revolução burguesa no Brasil. Com efeito, estabelecido já um capitalismo supostamente desenvolvido, em vias de tornar-se imperialista - cuja gênese remonta ao escravismo colonial —, a revolução brasileira se traduz no programa de uma revolução socialista.

Isso posto, cumpre observar de início que a perspectiva do escravismo colonial se funda tanto numa crítica à tradição que vem do sentido da colonização de Caio Prado, quanto às formulações que procuram caracterizar a colônia como particularidade de um modo de produção universal.

Assim, de uma parte, essa perspectiva se funda na crítica da noção de capitalismo comercial, pejorativamente demonstrado aqui em termos de circulacionismo. O pressuposto é determinada leitura do materialismo histórico que toma a economia política como chave epistemológica para delimitar quaisquer modos de produção pré-capitalistas. Nessa chave, a produção é sempre a dimensão determinante: há, portanto, um primado geral, estabelecido a priori, da produção sobre a circulação.

O que aqui se encontra em jogo é justamente o fundamento da explicação marxista dos sistemas econômicos, da história econômica. A questão é a seguinte: deve tal explicação basear-se essencialmente no exame do processo de produção, na medida em que o funcionamento do processo de circulação supõe a criação anterior de um excedente econômico? A resposta de Marx é categoricamente afirmativa. (Cardoso, 1974, p. 87)

Como desdobramentos, se observa, tal qual em Sodré, uma caracterização do Antigo Regime como um modo de produção feudal. Tanto quanto as monarquias são tomadas como Estados essencialmente feudais, o capital mercantil é considerado como um nexo pré-capitalista - como forma "antediluviana" do capital. Novamente, a princípio, um nexo exterior que vincula distintos modos de produção, diferentes "totalidades". Ao mesmo tempo, essa leitura relativiza o peso da exploração mercantil e colonial na acumulação primitiva e na formação do capitalismo, procurando sustentar o caráter contrarrevolucionário do capital mercantil - e, com isso, sublinha, mais que a exploração 
colonial, a centralidade dos vetores da acumulação primitiva internos às sociedades europeias.

É falsa a crença de que as transferências de excedente ao núcleo, da semiperiferia e da periferia foram o fator central do surgimento do capitalismo. Ao identificar capitalismo e relações de mercado, a articulação centro-periferia coloca-se só em termos de circulação (troca desigual), e a consequência obrigatória disto é uma teoria que faz total abstração da estrutura e das lutas de classes nas definições básicas (e isto tanto no que diz respeito aos países metropolitanos quanto aos periféricos. (Cardoso, 1982, p. 77)

Em suma, nessa visão, o sistema colonial não constitui a totalidade em que deve ser circunscrito o objeto, a colônia. Tampouco o escravismo colonial constitui, em si mesmo, uma totalidade absolutamente apartada das formações a que se liga por meio do capital mercantil. Como veremos, este será caracterizado mais rigorosamente como um "modo de produção dependente" e, nesse sentido, o sistema colonial será definido como uma "estrutura de estruturas" (Cardoso, in Lapa, 1980). Noutros termos: se é certo que o escravismo colonial possui vínculos mercantis, de outro lado, não se define por eles. Seguindo uma terminologia típica das teorias da dependência, esse "modo de produção dependente" será determinado por uma combinação complexa de estruturas "internas" e "externas", sob a primazia das primeiras.

Precisamente esse ponto esclarece o segundo vetor de críticas em que se funda a perspectiva do escravismo colonial: a crítica às tentativas de caracterização do modo de produção colonial como forma particular de um suposto modo de produção universal - o escravismo ou o feudalismo "puro e simples" de Sodré, por exemplo. A esse respeito, a perspectiva do escravismo colonial observa, a nosso ver corretamente, que, como vimos, na formulação do encadeamento sucessivo dos modos de produção, Marx realiza um percurso retrospectivo, não propriamente histórico, destacando formas de produção no espaço europeu-mediterrâneo que, de um ponto de vista estritamente lógico, revelam etapas progressivas no desenvolvimento das forças produtivas. Uma transposição, sem mediações, de um nível lógico para o nível da História faria sacrificar o concreto em favor do conceito. A História, por sua vez, deve buscar 
exatamente a especificidade - e disso deve dar conta o conceito de modo de produção mobilizado em cada caso. Nesse sentido, o escravismo colonial é um modo de produção específico que não se confunde com o "escravismo puro e simples", e sua especificidade reside justamente em seu caráter colonial. Trata-se, pois, de um modo de produção dependente.

Sobre essa base, Gorender propõe a elaboração das leis de movimento do modo de produção, nos termos de uma economia política do escravismo colonial. Nos limites do presente trabalho, não é possível retomar o conjunto das "leis" desse "modo de produção", senão discutir a "lei" referida à inversão inicial para aquisição do escravo que, nessa perspectiva, permite exprimir o ponto crucial quanto às condições de acumulação da economia colonial. Pois trata-se de esterilização do fundo produtivo disponível a ser reposto pelo trabalho excedente do escravo ao longo de sua vida útil - um dispêndio constitutivo da forma de propriedade escravista, derivado de sua racionalidade específica. A esterilização do fundo produtivo representa um "fluxo desacumulador", um desvio de parte substancial do excedente para a manutenção do tráfico. Ou seja: o limite à acumulação da economia colonial reside na especificidade do modo de produção escravista relativa à esterilização do fundo produtivo com vistas à manutenção do tráfico, mais que na exploração mercantil pela órbita da circulação. Enfim, o escravismo colonial, funcionando segundo sua própria racionalidade, demarcava os limites de suas possibilidades.

Não é difícil concluir que a importação de escravos constituía uma desacumulação, um corte nas possibilidades de acumulação de fundos produtivos, uma redução sempre substancial dos recursos poupados para investimento. Nem é preciso mais do que isto a fim de demonstrar o caráter, não somente pré-capitalista, mas também anticapitalista, do regime escravista colonial. [...] Se ajuntarmos este efeito desacumulativo aos demais efeitos da conservação da estrutura escravista e à continuação da espoliação colonialista, implícita no escravismo, teremos explicado o retardo do desenvolvimento econômico do Brasil na mesma época em que a economia capitalista avançava impetuosamente na Europa Ocidental e nos Estados Unidos. [...] É igualmente improcedente o argumento [...] segundo o qual o obstáculo ao desenvolvimento econômico não adveio do escravismo como tal, mas da agricultura de exportação. Ora, a predominância da agricultura de expor- 
tação não foi coincidência acidental, mas fator intrínseco ao modo de produção escravista colonial. (Gorender, 1992, p. 204-205)

Além disso, cumpre observar que, dada a tendência ao crescimento vegetativo negativo da população escrava, tal fluxo desacumulador correspondia à dependência estrutural para reproduzir esse modo de produção em relação ao tráfico.

No entanto - e aí parecem residir as dificuldades —, partindo da produção como dimensão determinante a priori, Gorender procura sustentar que a circulação constitui um momento subordinado e, pois, uma peça funcional determinada pela dinâmica do escravismo colonial. ${ }^{4}$ A rigor, Gorender inverte a tese da exploração colonial: porque a acumulação no escravismo engendra a esterilização do fundo produtivo, a empresa somente será rentável se o comércio for monopolista. Um sistema de preços monopolistas na venda de gêneros tropicais ou de manufaturados metropolitanos oferece um campo comum em que jogam os interesses dos proprietários coloniais, dos mercadores e das manufaturas metropolitanas, em disputa pelo excedente - para Gorender, a disputa é permanente; a exploração do proprietário pelo mercador é acidental.

Ora, é curioso escapar a Gorender justamente a existência da burguesia mercantil, que, sendo uma classe de intermediários por excelência, só pode viver dos lucros obtidos na circulação sobre o excedente criado na produção - para não mencionar as exaustivas referências de Marx quanto à importância do sistema colonial na acumulação primitiva. Trata-se, pois, da própria lógica do capital mercantil. Diante disso, cumpre sublinhar o domínio do capital mercantil sobre os transportes, a comercialização e o financiamento da produção colonial - bastante conhecida é a história da presença do capital mercantil holandês, por exemplo, no negócio do açúcar na América portuguesa. Curioso também que lhe escape que o vetor do fluxo desacumulador correspondente à esterilização do fundo produtivo seja justamente o tráfico de escravos, controlado pelo capital mercantil e, portanto, sujeito às mesmas condições de explo-

\footnotetext{
4. Notemos que, para Marx, no capitalismo constituído, o capital comercial é forma subordinada, porquanto se apropria de uma parte da mais-valia criada no momento da produção. Mas quando se trata do capital mercantil "pré-capitalista", a órbita da circulação permanece exterior à produção.
} 
ração por meio do controle monopolista sobre os dois polos da troca - aliás, sabidamente, um dos setores mais lucrativos do comércio colonial. No conjunto, o que faz Gorender supor que, sob o peso do exclusivo metropolitano, os proprietários coloniais controlassem os preços dos gêneros tropicais e, pois, as condições de distribuição do excedente? Se é assim, o que define o caráter de uma colônia? O que distingue uma colônia de uma metrópole? Como explicar a posição política dos proprietários coloniais no momento da emancipação?

Entendemos que a perspectiva do escravismo colonial aponta corretamente as tensões entre o plano conceitual e a História presentes nas tentativas de caracterizar a sociedade colonial como expressão particular de modos de produção universais por meio de uma redução do problema à dimensão das formas de produção escravistas ou servis. No entanto, entendemos que tal perspectiva fica no meio do caminho, porquanto deixa à margem de qualquer historicização as relações entre as dimensões da produção e da circulação, passo fundamental para enquadrar essas formas de trabalho compulsório cuja especificidade consistia em ser coloniais, sob o domínio, em última instância, do capital mercantil. Curiosamente, quanto a esse ponto central, é, por outro lado, a já referida observação de Sodré, segundo a qual, à época do capital mercantil, a "circulação comanda a produção", que, embora, como vimos, destacada de seu marco conceitual, aponta numa direção mais fecunda.

Se as formações pré-capitalistas devem ser consideradas no quadro da totalidade a que pertencem, não se reduzindo a um conjunto de determinações estritamente econômicas, a historicização do nexo entre "produção" e "circulação" constitui um passo fundamental. Tanto mais se consideramos tratar-se, no caso da colônia escravista, de uma forma de produção em que a própria presença física da massa de trabalhadores depende de um movimento prévio da circulação determinado pelo tráfico.

$\mathrm{O}$ ponto fica mais claro na crítica de Gorender às tentativas de estabelecer um nexo entre a expropriação do excedente colonial pela troca desigual e a exploração do trabalho compulsório nas colônias (Novais, 1995). Para Gorender, a condição monopolista do capital mercantil garantida pelos mecanismos de exclusivo torna-se, digamos, "matematicamente" inviável, porquanto a exploração do excedente das colônias no momento de compra dos gêneros coloniais, 
por si só, inviabiliza o outro polo da exploração no momento da venda dos produtos metropolitanos. Para Gorender, a resposta de inspiração furtadiana, segundo a qual tal equação se resolveria com a exploração do trabalho compulsório (ou, noutros termos, com a "concentração da renda" nas colônias), simplesmente deslocaria o problema para uma disputa em torno do excedente na órbita da circulação, sem dar conta do impasse "matemático" revelado pela análise da produção.

Contudo, entendemos que é preciso considerar que o processo de acumulação primitiva envolvia justamente formas violentas expropriação, no momento em que os mecanismos da mais-valia relativa não vigoravam. Não por outra razão, as próprias concepções mercantilistas se fundavam na ideia de uma economia estática em que o lucro mercantil só poderia existir à custa da troca desigual e da expropriação nua e crua - tanto quanto, no mundo do sistema colonial, a riqueza de um Estado se fazia à custa de outros. Com efeito, as tensões, que não se resolvem "matematicamente" por uma teoria do valor estática - esta também histórica - , serão criadas e recriadas, reproduzindo-se em escala progressivamente mundial, num quadro de guerras permanentes - sobretudo guerras coloniais. Mais que isso, nos momentos de crise, o capital mercantil encontrará uma saída pela expansão horizontal das zonas exploradas pela "periferização" de "arenas externas" (Wallerstein, 1974). Do mesmo modo, a reprodução do capital por meio dos mecanismos de "mais-valia absoluta", típica da época de transição ao capitalismo, supunha, como também demonstrou Marx, um regime de controle estrito sobre o trabalho, seja nas manufaturas metropolitanas, seja nas explorações coloniais. No caso da colônia escravista, o trabalho compulsório podia chegar ao limite da destruição física do próprio produtor, porque a África terminou por constituir-se num enorme reservatório de gente permanentemente levada à força a serviço do capital mercantil, renovando-se os contingentes coloniais por meio do tráfico - este também negócio mercantil lucrativo. Daí porque também não é possível conceber o "escravismo colonial" na América sem considerar, como parte do conjunto, os processos de diferenciação próprios do continente africano, que explicam as bases históricas sobre as quais se fundaram o tráfico, bem como o concurso do capital mercantil europeu que converteu a escravidão africana em produção massificada de escravaria. 
Assim, podemos questionar: quais as relações de produção em causa, senão as relações de produção do "sistema" como um todo, ${ }^{5}$ estas regidas pelo capital mercantil em estreita vinculação com as monarquias em formação?

\section{Conclusão}

Procuramos demonstrar que a conceitualização do modo de produção colonial em Sodré conduz a uma tensão entre o escravismo "puro e simples" e o sentido histórico da formação nacional. Com efeito, não escapa a Sodré as determinações mercantis referidas à exploração colonial como um vetor da acumulação primitiva. Mas o modo de produção, central para a caracterização da colônia, surge como uma dimensão conceitual justaposta à própria História, sem que se explicitem as mediações entre um plano e outro. A perspectiva do "escravismo colonial" tenta, a seu modo, dar conta do problema, buscando a construção da economia política de um modo de produção específico cuja especificidade reside exatamente no seu caráter colonial e que vem a ser, ao fim e ao cabo, um "modo de produção dependente". Mas como pensar, a partir de uma primazia preestabelecida da produção sobre a circulação, a autonomia, mesmo que relativa, de um modo de produção cuja massa de trabalhadores escravizados é, necessariamente, produto de um movimento prévio da circulação? Naturalmente, um movimento presidido pelo capital mercantil, que faz entrelaçar de forma orgânica os três continentes. Nesse sentido, como considerar acidental a exploração do excedente por meio da circulação?

5. “O ponto é que as 'relações de produção' que definem um sistema são as 'relações de produção' do sistema como um todo" (Wallerstein, 1974, v. I, p. 129).

6. Quanto a esse ponto, a observação de Fernando Novais com respeito às críticas referidas a um suposto (e pejorativo) "circulacionismo" é esclarecedora. "Externalidade da acumulação originária de capital autônomo refere-se à área de produção (as colônias) em direção às metrópoles; nada tem que ver com um processo externo ao sistema, que envolve por definição metrópoles e colônias. Não cabe, portanto, a increpação de obsessão com as relações externas (porque não estamos falando de nada externo ao sistema), nem de desprezo pelas articulações internas, pois estas não são incompatíveis com aquelas. [...] Uma questão que sempre me ocorre diante desses argumentos é esta: se não são essas as características (extroversão, externalidade da acumulação etc.) fundamentais e definidoras de uma economia colonial, o que, então, as define? Ou será que não se definem? Será que nada de essencial as distingue das demais formações econômicas?" (Novais, 1999, p. 448). 
Entendemos que tais percalços revelam a pertinência da perspectiva que confere centralidade às teias mercantis na determinação do sentido da colonização, desnudando o papel do sistema colonial na formação do modo de produção capitalista. Mais que isso, essa perspectiva permite captar as linhas de continuidade que ligam o passado colonial ao Brasil contemporâneo, na medida em que procuram identificar, no desenvolvimento do capital mercantil e do antigo sistema colonial, as raízes do capitalismo moderno, do imperialismo. ${ }^{7} \mathrm{~A}$ esse respeito, Caio Prado (1978, p. 80) observa:

[...] no Brasil, em cujo território descoberto e colonizado pelos europeus, se constituiu uma nacionalidade cujas raízes se situam no próprio complexo cultural que daria origem, mais tarde, ao imperialismo; e cuja organização econômica, social e política se plasmaria, por conseguinte, em função de circunstâncias e padrões que são os do mesmo sistema que daria, nos dias de hoje, no imperialismo. Em outras palavras, o processo de colonização brasileira de que resultou o nosso país e suas instituições econômicas, sociais e políticas, tem sua origem nessa mesma civilização e cultura ocidentais que seriam o berço do capitalismo e do imperialismo.

Tal observação se torna tão mais aguda quanto essa mesma formação, sob o jugo do imperialismo contemporâneo, naufraga num processo reversivo que lhe reconstitui traços marcantes de uma sociedade e, em particular, de uma economia colonial. O peso do passado permanece.

\section{Recebido em 23/9/2016 - Aprovado em 16/2/2017}

\footnotetext{
7. Não queremos dizer com isso que concordamos com as visões que caracterizam o sistema colonial e a colônia nos termos de um “capitalismo" já constituído, o que revelaria uma confusão entre o domínio do capital mercantil e modo de produção capitalista. O debate em torno da transição do feudalismo ao capitalismo é bastante complexo e escapa aos limites deste trabalho. Contudo, é necessário explicitar, mesmo que pontualmente, nossa posição: entendemos que o período que vai do século XVI à Revolução Industrial de fins do século XVIII, se não pode ser caracterizado nos termos de um modo de produção capitalista já constituído, também não pode ser caracterizado como feudal; trata-se de um período específico de transição, em que se definem hierarquias no plano do capitalismo mundial, as quais se plasmarão, no momento seguinte, no imperialismo contemporâneo.
} 


\section{Referências bibliográficas}

CARDOSO, C. A afro-américa. 3. ed. São Paulo: Brasiliense, 1982.

et al. Modos de producción en América Latina. 2. ed. Córdoba: Passado y Presente, 1974.

CARDOSO DE MELLO, J. M. O capitalismo tardio. 9. ed. São Paulo: Brasiliense, 1998. FURTADO, C. Formação econômica do Brasil. 25. ed. São Paulo: Nacional, 1995. . Brasil: a construção interrompida. 3. ed. Rio de Janeiro: Paz e Terra, 1992.

GORENDER, J. O escravismo colonial. 6. ed. São Paulo: Ática, 1992. . A burguesia brasileira. 3. ed. São Paulo: Brasiliense, 1990.

GUIMARÃES, A. P. Quatro séculos de latifúndio. 5. ed. Rio de Janeiro: Paz e Terra, 1981.

HOBSBAWM, E. Introdução. In: MARX, K. Formações econômicas pré-capitalistas. 2. ed. Rio de Janeiro: Paz e Terra, 1977.

LAPA, J. R. do A. (Org.). Modos de produção e realidade brasileira. Petrópolis: Vozes, 1980.

MARX, K. Formações econômicas pré-capitalistas. 2. ed. Rio de Janeiro: Paz e Terra, 1977.

. O capital: crítica da economia política. 3. ed. São Paulo: Nova Cultural, 1988.

NOVAIS, F. Portugal e Brasil na crise do antigo sistema colonial. 6. ed. São Paulo: Hucitec, 1995.

. Condições da privacidade na colônia. In: SOUZA, L. de M. (Org.). História da vida privada no Brasil. São Paulo: Companhia das Letras, 1999. v. I.

SAMPAIO JR., P. de A. Entre a nação e a barbárie. Petrópolis: Vozes, 1999.

PRADO JR., C. Formação do Brasil contemporâneo. 11. ed. São Paulo: Brasiliense, 1971.

. A revolução brasileira. 6. ed. São Paulo: Brasiliense, 1978. 
SODRÉ, N. W. Formação histórica do Brasil. 9. ed. São Paulo: Civilização Brasileira, 1976.

. Introdução à revolução brasileira. 4. ed. São Paulo: Ciências Humanas, 1978.

. Capitalismo e revolução burguesa no Brasil. Belo Horizonte: Oficina de Livros, 1990.

. História e materialismo histórico no Brasil. São Paulo: Global, 1987.

TAVARES, M. da C. Acumulação de capital e industrialização no Brasil. 3. ed. Campinas: Unicamp-IE, 1998.

VIANNA, O. Instituições políticas brasileiras. Niterói: Eduff, 1987.

WALLERSTEIN, I. O sistema mundial moderno. Porto: Afrontamento, 1974. 